\title{
Oral Healthcare Renunciation and Socioeconomic Determinants
}

\section{Mbathio Diop ${ }^{*}$, Aida Kanoute ${ }^{1}$, Massamba Diouf', Mamadou Lamine Guirassy ${ }^{1}$, Ndeye Marème Sougou ${ }^{2}$, Amadou Diaw Ndiaye ${ }^{1}$, Cheikh Mouhamadou Mbacké Lôo ${ }^{1}$, Daouda Faye1, Daouda Cissé 1}

${ }^{1}$ Department of Odontology, Faculty of Medicine, Pharmacy \& Odonto-Stomatology, Cheikh Anta Diop University, Dakar, Senegal

${ }^{2}$ Department of Public Health Faculty of Medicine, Cheikh Anta Diop University, Dakar, Senegal

Email: *diopmbathio@yahoo.fr

How to cite this paper: Diop, M., Kanoute, A., Diouf, M., Guirassy, M.L., Sougou, N.M., Ndiaye, A.D., Lô, C.M.M., Faye, D. and Cissé, D. (2018) Oral Healthcare Renunciation and Socioeconomic Determinants. Open Journal of Epidemiology, 8, 109-116.

https://doi.org/10.4236/ojepi.2018.83009

Received: January 14, 2018

Accepted: August 5, 2018

Published: August 8, 2018

Copyright (c) 2018 by authors and Scientific Research Publishing Inc. This work is licensed under the Creative Commons Attribution International License (CC BY 4.0).

http://creativecommons.org/licenses/by/4.0/

\begin{abstract}
The unequal access to healthcare in general and oral healthcare, in particular, is a true public health concern. Thus, it is important to assess the oral healthcare renunciation and socioeconomic determinants to take appropriate measures. A cross-sectional, descriptive population-based study of 300 households was carried out between April 28, 2016, and May 28, 2016, according to WHO's guidelines (Protocol 1997), in Senegal adapted form. Results showed that $18.23 \%$ of householders report that their household members have foregone oral healthcare. Among those who renounced care, 51.5\% did so for care costs $(24.2 \%)$ or remoteness of health facilities $(27.3 \%)$ reasons. Therefore, dental treatment renunciation was independently associated to income level, age, sex, marital status, and types of oral healthcare coverage. This study's analysis shows that oral healthcare renunciation depends primarily on the financial aspect and the remoteness of health structures. Still, there are other important socio-anthropological parameters that should be investigated.
\end{abstract}

\section{Keywords}

Determinants, Health Insurance, Oral Healthcare, Renunciation, Senegal

\section{Introduction}

Oral healthcare access is a real health issue. Sure enough, costs of these pathologies which are among the world's most expensive ones are ranked fourth in the list of most costly illnesses [1]. On Top of that, the social protection system in 
Africa is very weak. In Senegal, the social coverage rate is $20 \%$. To face up to this situation, the universal health coverage was set up with the expansion of mutual to facilitate the population's sanitary coverage [2]. Insurance companies' ability to minimize the healthcare renunciation has been a focus of the public health debate. Després et al. to explain "Individuals give up care when they do not request care and health professionals' services while they are experiencing a disorder, noticing a bodily or psychic disorder or when they underuse the prescribed care" [3]. Indeed, renunciation of care, which is an indicator of access to care, can occur at any moment of a therapeutic journey. This study aimed to analyze the oral healthcare renunciation and socioeconomic determinants.

\section{Methodology}

\subsection{Type of Study}

Epidemiological study (cross-sectional and descriptive).

\subsection{Target Population}

Volunteers inhabitants of towns which met the selection criteria

\subsection{Selection Criteria}

Adults inhabitants of selected towns who were 18 years old or over and in charge of the family's medical care.

\subsection{Sampling}

Three hundred householders from 12 localities, as recommended by WHO, were selected [4] (Table 1).

The statistical population number was determined according to WHO's guidelines described in its basic methods which suggest a sample of 300 households from 12 sites [4].

Table 1. Summary of selected localities.

\begin{tabular}{ccccc}
\hline Regions & $\begin{array}{c}\text { Nuùber } \\
\text { Households }\end{array}$ & Departments & Communes & Municipalities \\
Dakar & 100 & $\begin{array}{c}\text { Dakar } \\
\text { Rufisque }\end{array}$ & $\begin{array}{c}\text { Dakar-plateau } \\
\text { Rufisque }\end{array}$ & $\begin{array}{c}\text { Gorée, Gueule-tapée, } \\
\text { Fass Colobane, Rufisque } \\
\text { Diourbel }\end{array}$ \\
Thiès & 50 & Mbacké & Ndame & Missirah, Touba mosquée \\
Louga & 25 & Thiès & Keur Moussa & Fandène, Keur Moussa \\
Saint-Louis & 25 & Kébémer & Ndane & Dioukoul Diawrigne \\
Kaffrine & 25 & Saint-Louis & Rao & Fass Ngom \\
Kaolack & 25 & Mbirkilane & Mabo & Mabo \\
\hline
\end{tabular}




\subsection{Variables and Indicators Used}

The information collected to analyze the renunciation refers to age, gender, householders' income, education level, and type of medical coverage,

\subsection{Data Collection}

A questionnaire form, a statistician and two dental surgeon students were utilized to carry out this study and collect data from April 28, 2016 to May 29, 2016.

A correspondence for approval was sent to medical authorities, the ethics committee before running the survey.

Aims and the importance of the survey were explained to populations for their free and enlightened consent. After the interview, the surveyed family received oral hygiene instructions.

\subsection{Data Analysis}

CS Pro software version 6.3 was used to analyze the data, graphical representation was done with the $\mathrm{R}$ software and tables and charts were done using the SPSS software. Results were expressed in terms of proportion and averages. The Chi two test was used to compare qualitative data.

\section{Results}

\subsection{Socio-Demographic Characteristics of Households}

The study was carried out in 300 households. Householders were on average 45 years old with a standard deviation of 15 years. Over half of surveyed households (58.30\%) have more than six (6) members. Nearly half of householders $(48.7 \%)$ have a monthly income of less than CFAF 50,000 and only 5.7\% of householders earn CFAF 300,000 and over ( 1 USD $=610$ FCFA $)$.

\subsection{Oral Healthcare Renunciation}

More than 3/4 of householders (81.9\%) state that members of their household have never given up care. For those who have renounced care, $51.5 \%$ of them blame it on care costs $(24.2 \%)$ or the remoteness of health structures $(27.3 \%)$ (Table 2).

Table 2. Oral healthcare renunciation and its reasons.

\begin{tabular}{ccccccc}
\hline \multirow{2}{*}{ Variables } & $\begin{array}{c}\text { Terms and } \\
\text { conditions } \\
(1000 \text { CFA F })\end{array}$ & Numbers & Percentage & Confidence interval \\
Waiver of care & Yes & 33 & 18.33 & 12.48 & 23.78 \\
& No & 149 & 81.87 & 76.21 & 87.52 \\
Reasons for renouncing on & Distance & 9 & 24.2 & 9.59 & 38.81 \\
healthcare & Transport & 1 & 27.3 & 12.10 & 42.5 \\
& Other & 15 & 45.5 & 28.51 & 62.49 \\
\hline
\end{tabular}




\subsection{Oral Healthcare Renunciation and Socio-Economic Characteristics (Table 3)}

Table 3. Oral healthcare renunciation and sociodemographic determinants.

\begin{tabular}{|c|c|c|c|c|c|c|}
\hline \multirow{3}{*}{ Variables } & \multirow[t]{3}{*}{ Methods } & \multicolumn{4}{|c|}{ Waiver of care } & \multirow{3}{*}{$\begin{array}{c}\text { Chi two } \\
\text { test/Fisher } \\
\text { exact } \\
\text { p-value }\end{array}$} \\
\hline & & \multicolumn{2}{|c|}{ Yes } & \multicolumn{2}{|c|}{ No } & \\
\hline & & Numbers & $\begin{array}{c}\text { Percentage } \\
(\%)\end{array}$ & Numbers & $\begin{array}{c}\text { Percentage } \\
(\%)\end{array}$ & \\
\hline \multirow{2}{*}{ Gender } & Man & 9 & 12.86 & 61 & 87.14 & \multirow{2}{*}{0.137} \\
\hline & Wife & 24 & 21.62 & 87 & 78.38 & \\
\hline \multirow{7}{*}{ Age } & $<30$ & 6 & 25.00 & 18 & 75.00 & \multirow{7}{*}{0.972} \\
\hline & $30-39$ & 7 & 18.42 & 31 & 81.58 & \\
\hline & $40-49$ & 9 & 16.98 & 44 & 83.02 & \\
\hline & $50-59$ & 6 & 20.69 & 23 & 79.31 & \\
\hline & $60-69$ & 4 & 14.81 & 23 & 85.19 & \\
\hline & $70-79$ & 1 & 14.29 & 6 & 85.71 & \\
\hline & $>80$ & 0 & 0.00 & 3 & 100.00 & \\
\hline \multirow{4}{*}{ Marital status } & Married & 29 & 18.47 & 128 & 81.53 & \multirow{4}{*}{0.127} \\
\hline & Divorced & 3 & 33.33 & 6 & 66.67 & \\
\hline & Widow (er) & 0 & 0 & 12 & 100 & \\
\hline & Single & 1 & 33.33 & 2 & 66.67 & \\
\hline \multirow{4}{*}{ Education level } & $\begin{array}{c}\text { Never } \\
\text { schooled }\end{array}$ & 13 & 15.66 & 70 & 84.34 & \multirow{4}{*}{0.289} \\
\hline & Primary & 8 & 17.78 & 37 & 82.22 & \\
\hline & Secondary & 11 & 28.21 & 28 & 71.79 & \\
\hline & $\mathrm{Bac}+$ more & 1 & 7.14 & 13 & 92.86 & \\
\hline \multirow{4}{*}{$\begin{array}{c}\text { Income level } \\
(1 \text { USD }=610 \\
\text { FCFA })\end{array}$} & $<100$ & 23 & 20.72 & 88 & 79.28 & \multirow{4}{*}{0.336} \\
\hline & $100-300$ & 4 & 25.00 & 12 & 75.00 & \\
\hline & $>300$ & 2 & 16.67 & 10 & 83.33 & \\
\hline & $\mathrm{PR}^{2}$ & 4 & 9.52 & 38 & 90.48 & \\
\hline \multirow{4}{*}{$\begin{array}{c}\text { Medical } \\
\text { coverage types }\end{array}$} & $\begin{array}{l}\text { Budget } \\
\text { allocation }\end{array}$ & 1 & 16.67 & 5 & 83.33 & \multirow{4}{*}{0.912} \\
\hline & $\mathrm{DPI}^{3}$ & 3 & 23.08 & 10 & 76.92 & \\
\hline & Mutual & 6 & 20.69 & 23 & 79.31 & \\
\hline & Yourself & 23 & 17.29 & 110 & 82.71 & \\
\hline
\end{tabular}

\section{Discussion}

\subsection{Households Socio-Demographic Characteristics}

Householders' income level is a key element in analyzing their ability to take care, on their own, of their oral healthcare. However, nearly half of householders 
(48.7\%) have less than 50,000 FCFA monthly income and only 5.7\% earn over 300,000 FCFA ( 1 USD $=610$ FCFA). This is due to the predominance of women householders who devote most of their time to domestic activities, maternity and childcare [5]. These data coincide with those found in Burkina Faso where the average per capita monthly income (per capita) is 7945 FCFA, along significant disparities according to the householder socio-economic profile [6]. However, to note that $28.3 \%$ of households' income could not be verified for confidentiality measures and, in some cases, the head was absent and the questionnaire was administered to the spouse who had no access to the income information.

\subsection{Oral Healthcare Renunciation}

Over $3 / 4$ of householders $(81.9 \%)$ said that members of their household have never renounced care. Among those who renounced care at least once, 51.5\% of them blame it on care costs $(24.2 \%)$ or the remoteness of health facilities (27.3\%). Still, $45.5 \%$ of householders raised other reasons for giving up care at least once. This could be due to the use of other practices. Diop's 2016 study shows that $37.3 \%$ of households use traditional medicine, $32.3 \%$ self-medicate themselves and only $25 \%$ reach out to dentists for dental pain [7]. Similarly, a study conducted in Ivory Coast highlights the main reasons for using traditional care such as the affordable cost of treatment $(73.8 \%)$, the nonexistence of pain during care $(20.9 \%)$, the proximity of traditional healers $(20.3 \%)$ and the effectiveness of traditional care (17.9\%) [8]. Also, similar results have been found in studies in Burkina Faso and India where people with dental pain use many known African plants [9] but also a variety of self-medication methods to deal with their pain [10].

\subsubsection{Oral Healthcare Renunciation and Householder Gender}

The quit rate for oral health care is $18.23 \%$ of the study population with disparities among groups in this population. Thus, this rate appears lower for men than for women with $12.86 \%$ and $21.62 \%$ respectively. Yet, there is not any statistical link between the householder gender and oral healthcare renunciation (Table 3 ). Women are more likely to give up on care for financial reasons than men. A persistent fact, regardless of the type of care and which remains unvarying over the course of life [11]. Reasons are rather due to the state of subjective health: at a state of comparative health women tend to consider themselves as being in poor health as men [12].

\subsubsection{Oral Healthcare Renunciation and Householders' Marital Status}

Table 3 shows that single and divorcees renounce to care more than married and widowers. Indeed, the rate of renunciation is $33.33 \%$ among single and divorcees against $18.7 \%$ among married and nil among widowers. The renunciation varies according to individuals, their history of care, of life, their environment, their profession, their socio-cultural level [13]. 


\subsubsection{Oral Healthcare Renunciation and Householders' Income Level}

Cross-checking care renunciation with householders' income level shows that householders that have greater monthly income ( $>300$, more than FCFA $300,000)$ give up oral healthcare the least $(11.76 \%)$. Whereas, in middle-income (between CFA 100,000 and 300,000) and low-income (less than FCFA 100,000) householders, the quit rate is relatively high compared to the overall rate. Thus, it is at $25.00 \%$ and $20.72 \%$ respectively for householders in middle and low-income to $18.23 \%$ at the global level. Still, statistical statistics relationship does not show any link between the renunciation and the householders income level (Table 3). Econometric work has particularly shown the importance of social precariousness among renunciation determinants [14] [15]. Financial reasons are the most common factor of dental care renunciation [3].

\subsubsection{Oral Healthcare Renunciation and Householders' Age}

The analysis of renunciation by the age group of householders shows interesting results. Thus, except for the 50 - 59 years-old age groups, the renunciation rate decreases as the householder gets older. It goes from $20 \%$ in households whose head is under 30 years old to $14.29 \%$ in those between 70 and 79 years old. For households whose head is between 50 and 59 years old, the quitting rate is $20.69 \%$, whereas it is respectively $16.98 \%$ and $14.81 \%$ in the 50 year-old age groups, 59 years old (40 - 49 and 60 - 69). Still, the exact Fisher statistic shows no statistical link between renunciation and the householder age (Table 3). Nevertheless, dental care renunciation decreases sharply at high ages, with the decrease in needs themselves [11].

\subsubsection{Oral Healthcare Renunciation and Householders' Education Level}

The analysis of oral healthcare renunciation according to the householder education level shows that the rate of renunciation is lower among those who have reached university level (7.14\%), followed by the never-enrolled (15.66\%) and those with primary education (17.78\%), all of which are below the overall rate. On the other hand, the quit rate is strangely relatively high among households whose head is at the secondary level, which, thus, stands at $28.21 \%$ against $18.23 \%$ overall. The fisher exact statistic reveals no statistical link between householders' level of education and oral healthcare renunciation (Table 3). These results mirror those of Vanobbergen et al. [16] which show the impact of health education on lifestyle. A similar study conducted in Ivory Coast reports that $44.4 \%$ of traditional practitioner users do so for financial reasons.

Canadian data [17] showed that renunciation' factors differ according to its causes (long queues, financial barriers or personal reasons).

\subsubsection{Oral Healthcare Renunciation and Care Coverage}

The quit rate for oral care is relatively higher among DPI beneficiaries. Indeed, it is $23.08 \%$ against $20.69 \%$ among mutual beneficiaries and even lower among CB beneficiaries. It should be pointed out that those who pay for care on their own have a lower quit rate than mutual enrollees, which raises questions about their 
effectiveness and degree of coverage. A plausible hypothesis would be that those who take care of themselves have somehow the means to cover costs of care, at least up to a certain level, whereas mutual beneficiaries cannot afford to pay some unsupported types of care. Diop's study shows that mutual generally cover two types of care: conservative care and dental extractions [18]. They covered $51.2 \%$ of their members for conservative care and $53.5 \%$ for dental care extractions. As compared to Manski's study, people without coverage and without dental care, dental care coverage beneficiaries were more likely to be younger, female, wealthy, college graduates, married, in excellent or very good health, and not missing all their permanent teeth [19]. Studies showed that low-income and non-dental insurance respondents were four times more likely to avoid a dental professional because of the cost and about two and a half times more likely to refuse a recommended dental treatment because of the cost [20].

\section{Conclusion}

Care renunciation is an important indicator of access to care. The study enables to test the socio-economic characteristics' effect on oral healthcare renunciation. This study's results are usually consistent with those obtained in the literature. Variable revenue plays an important role. However, the renunciation of care is not limited to the financial issue. It also shows that social factors have a distinct influence on renunciation. Furthermore, the coverage type reveals atypical results because health insured households tend to forgo care. This can be justified by the partial coverage of care. In the end, the results of the work on renunciation suggest that the issue of access is more complicated than that of the right of access. In addition, the CMU-C appears to be a step in contending with care renunciation for financial reasons.

\section{References}

[1] World Dental Federation (2011) Leading the World to Optimal Oral Health, The FDI 2020 Vision. A Survey on the Future of Oral Health 2011.

[2] National Agency of Statistics and Demography (2012) (ANSD) [Senegal], and ICF International. Demographic and Health Survey with Multiple Indicators in Senegal (EDS-MICS) 2010-2011. ANSD and ICF International, Calverton, Maryland, 520 p.

[3] Desprès, C., Dourgnon, P., Fantin, R. and Jusot, F. (2011) The Renunciation of Care: A Socio-Anthropological Approach. Question of Health Economics, No. 169.

[4] World Health Organization (1997) Oral Health Surveys: Basic Methods. 4th Edition, World Health Organization, Geneva.

[5] Lopez, R. and Baelum, V. (2007) Factors Associated with Dental Attendance among Adolescents in Santiago, Chile. BMC Oral Health, 7, 1. https://doi.org/10.1186/1472-6831-7-4

[6] Kaboré, W.A.D., CDW Ouedraogo, Konaté A, Traoré RG, Knight V, Boisramé S. (2016) Self-Medication for Oral Diseases in Ouagadougou, Burkina Faso. Journal of Oral Medicine and Oral Surgery, 22, 277-84.

[7] Diop, M., Kanouté, A., Diouf, M., Ndiaye, A.D., Lo, C.M., Faye, D. and Cisse, D. (2017) Behavior of the Access to Oral Health Care in Senegal. Edorium Journal of 
Public Health, 4, 58-68.

[8] Sangare, A.D., Samba, M. and Bourgeois, D. (2012) Illness-Related Behavior and Sociodemographic Determinants of Oral Health Care in Dabou, Ivory Coast. Community Dental Health Journal, 29, 78-84.

[9] Nuel, C. (2009) Importance of Traditional African Medicine in the Treatment of Diseases of the Oral Cavity in Burkina Faso. Thesis Chir. Dent. University of Nancy, \# 1.

[10] Jaiswal, A.K., Pachava, S., Sanikommu, S., Rawlani, S.S., Pydi, S. and Ghanta, B. (2015) Dental and Self-Care: A Cross-Sectional Study of People with Low Socio-Economic Status Residing in Rural India. International Dental Journal, 65, 256-260. https://doi.org/10.1111/idj.12180

[11] Des, C., Dourgnon, P., Fantin, R. and Jusot, F. (2011) The Renunciation of Care for Financial Reasons: Econometric Approach. Health Economics Question, 170, 2-6.

[12] Shmueli, A. (2003) Socio-Economic and Demographic Variation in Health and in Its Measures: The Issue of Reporting Heterogeneity. Social Science \& Medicine, 57, 125-134. https://doi.org/10.1016/S0277-9536(02)00333-7

[13] Desprès, C. (2011) Renoncer aux soinscommeforme de résistance à la médecine, Pratiques. Cahiers de la médecineutopique, No. 57, p. 70, avril 2011. https://pratiques.fr/-Pratiques-No-57-Non-au-sabotage-L-acces-aux-soins-en-danger

[14] Dourgnon, P., Despres, C., Jusot, F., Fantin, R., Dourgnon, P., Jusot, F. and Fantin, R. (2012) Paying Badly for Health: A Study of the Impact of Financial Renunciation of Care on Health Status. Public Economy, 28-29, 123-147.

[15] Renahy, E., Parizot, I., Vallée, J. and Chauvin, P. (2012) Pierre Chauvin. Le renoncement aux soins pour raisons financières dans l'agglomération parisienne : déterminantssociaux et évolution entre 2005 et 2010. Rapport de recherche pour la DREES. inserm-00645136.

http://drees.solidarites-sante.gouv.fr/IMG/pdf/3_RS_Pierre_Chauvin.pdf

[16] Vanobbergen, J., De Visschere, L., Daem, M., Ceuppens, A. and Van Emelen, J. (2010) Sociodemographic Determinants for Oral Health Risk Profiles. International Journal of Dentistry, 2010, Article ID: 938936.

[17] Allin, S., Grignon, M. and Le Grand, J. (2010) Subjective Unmet Need and Utilization of Health Care Services in Canada: What Are the Equity Implications? Social Science and Medicine, 70, 465-472. https://doi.org/10.1016/j.socscimed.2009.10.027

[18] Diop, M., Kanoute, A., Diouf, M., Ndiaye, A.D., Lo, C.M., Faye, D. and Cisse, D. (2017) Financial Access to Dental Care Trough Health Insurance in Senegal. Science Journal of Public Health, 5, 359-364. https://doi.org/10.11648/j.sjph.20170505.11

[19] Manski, R.J., Moeller, J.F. and Chen, H. (2014) Dental Care Coverage and Use: Modeling Limitations and Opportunities. The American Journal of Public Health, 104, e80-e87.

[20] Thompson, B., Cooney, P., Lawrence, H., Ravaghi V. and Quinonez C. (2014) Cost as a Barrier to Accessing Dental Care: Findings from a Canadian Population-Based Study. Journal of Public Health Dentistry, 74, 210-218.

https://doi.org/10.1111/jphd.12048 